\title{
Surfaces
}

\section{Alvin A. Lee, Robert Denham (eds). The Legacy of Northrop Frye. University of Toronto Press, 1994. 353 pages}

\section{Danielle Miller}

Volume 5, 1995

URI : https://id.erudit.org/iderudit/1065010ar

DOI : https://doi.org/10.7202/1065010ar

Aller au sommaire du numéro

Éditeur(s)

Les Presses de l’Université de Montréal

ISSN

1188-2492 (imprimé)

1200-5320 (numérique)

Découvrir la revue

Citer ce compte rendu

Miller, D. (1995). Compte rendu de [Alvin A. Lee, Robert Denham (eds). The Legacy of Northrop Frye. University of Toronto Press, 1994. 353 pages].

Surfaces, 5. https://doi.org/10.7202/1065010ar d'utilisation que vous pouvez consulter en ligne. 


\section{Book Review}

\section{Alvin A.Lee, RobertDenham eds : The Legacy of Northrop Frye}

Danielle Miller

Université de Montréal

Département de Littérature Comparée

Surfaces Vol. V.06 (v.1.0A - 23/12/1995)

Copyright for texts published in SURFACES remains the property of authors. However, any further publication should be accompanied by an acknowledgement of SURFACES as the place of initial publication.

ISSN: $1188-2492$

\section{Alvin A. Lee, Robert Denham (eds). The Legacy of Northrop Frye.University of Toronto Press, 1994. 353 pages.}

The Legacy of Northrop Frye is a well written and very readable collection of essays exploring (as the title suggests) the legacy of Northrop Frye. The 29 essays, the Poem "Norrie Banquet Ode," and the auditory masque "In the Middle of Ordinary Noise" were originally presented at an international conference, "The Legacy of Northrop Frye," held at Victoria College in the University of Toronto between October 29 and 311992.

The collection contains four sections, "The Double Vision: Culture, Religion, and Society," "Imagined Community: Frye and Canada," "The Visioned Poet in His Dreams: Frye, Romanticism, and the Modern" and "Dunsiname, Birnam Wood, and Beyond: Frye's Theoria of Language and Literature." Since the articles grouped under each heading frequently seem to converse with those of the other sections, complementing or shedding another point of view on a particular aspect, these sections are by no means autonomous entities. Furthermore not all the essays live up to the ambitious titles of each section. It is ironic, though understandable, that a work discussing a man who studied the" universals taught by poetry" does not provide a single coherent portrait of Frye (xi). Instead Lee and Denham present the reader with a well crafted collage of essays discussing various aspects of Frye's life, his obsessions, his theories, his contributions to Canadian arts, his friendships with other writers, and sometimes his articles on other authors. 
The Legacy of Northrop Frye refuses to monopolize the memory of Frye, suggesting instead a variety of possible legacies. It leaves the reader wanting to learn more about the man and the" fearful symmetries" that haunt his writing. For instance, the work includes contributions as diverse as Deanne Bogdan's application of her cycle of" initiation, separation and return" to Frye's /pp. 4-5/ theories, Sandra Djwa's piece telling of Frye's relationship to Pratt and of the poet's effect on the theorist's perception of nature, Clara Thomas' comparison of Margaret Laurence and Frye, and Eleanor Cook's discussion of Wallace Stevens' enigma and Frye. Although these last two pieces seem to deal mostly with Laurence and Stevens, with only lip service paid to the theorist, they are not out of place in this collection since they open another window on Frye.

Many contributors seem to view Frye's work as a possible way out of the present theoretical stalemate that paralyses literary studies. While Imre Salusinsky perceives the theorist as a true liberal who positions himself in the middle ground between" determinism" and" aesthetic indeterminacy," Michael Fischer sees him as someone who holds principles from both sides of the theorists and anti-theorists debate. Julia Kristeva finds Frye's valorisation of memory useful in an age of nihilism brought about by excesses of post-structuralism.

The Legacy of Northrop Frye, of course, contains the usual essays on metaphors and archetypes, as well as those on Frye's link to theories of deconstruction, communication, music, and painting. The absence of literary jargon renders these pieces accessible and enjoyable to the lay reader. Other contributors compare Frye to Shelley (Monica Lee), question his reading of Keates'" Endymion" (Helen Vendler), and argue that his opinions frequently interfere with a strictly rigorous poetic analysis of a work (Milton Wilson). Wilson concludes his piece by suggesting that" While [Frye's] mythopoeic criticism allows him to enter a poet's world, but does not necessarily push him to do much more, his deep-rooted rhetorical criticism always seems to be there to take up the evaluative slack" (152).

The final section of the book opens with an auditory masque by James Reaney and John Beckwith that attempts to trace an auditory portrait of Northrop Frye. Inspired by the theorist's statement that" A musical sound in the middle of an ordinary noise reminds us of music itself ... the whole range of possibilities," the masque strings together a series of Frye's observations / pp. 5-6/ against a backdrop of everyday noises. This piece not only provides a break from the essays but leaves the reader wishing he/she had seen/ heard the production.

The collection's greatest strength - it's refusal to impose one picture of Frye - is also its greatest weakness. There is a marked absence of any real attempt to take a critical distance from Frye and to question him on a more general level. Although Hayden White and Wladimir Krysinski respectively attempt to place him in the larger contexts of literary history and of modernity, Linda Hutcheon is the only contributor who steps back and addresses the frightening question of the" fearful symmetries" in Frye's oeuvre. By refusing to excuse them and to ignore them, Hutcheon begins to open a debate on the overall implications of Frye's writings. 
The length of the essays, however, may account for their lack of depth. Certainly the first section on religion is unsatisfactory. Religion may be an awkward topic to treat but it is central to understanding Frye and merits more profound attention than is paid to it in this collection of essays. Most disappointing, however, remains the section titled" Imagined Community: Frye and Canada" which fails to analyse/address Frye's perception of Canada. Instead the essays in this second section mostly assess Frye's reading of Canadian poetry and discuss his ties with other Canadian writers. Despite the authors' repeated mention of Frye's vision of the Canadian community, its history, and its future, they never describe this vision. It would have been interesting to read a discussion, an analysis, or even an explanation of this" imagined community." My final complaint with this second section is the intervention and the" Banquet Ode" written by Margaret Atwood. Frankly (and in keeping with the rhyme pattern in" Banquet Ode"), it is a bore!

In conclusion, The Legacy of Northrop Frye is an enjoyable and thoroughly accessible book. It doesn't read like a scholarly treaties and one does not need to have read all of Frye's work to enjoy the book and to appreciate his contributions to Canadian culture. Perhaps the collection should have been titled" The Legacies of Northrop Frye" since it does not give the reader simply one coherent assessment of the theorists or of his work. Instead, the collection provides many brief views into the life of Frye and suggests various possible legacies. Lee and Denham leave the reader to answer for him/herself the questions posed in the introduction to the work" What is the legacy left by Northrop Frye? And what might, or should, be done with this legacy?" Although some articles are not as extensive as one might like, the editors leave the reader wanting to know more about Frye rather than saturated with his legacy. 